\title{
Evidence of Renewable Energy Use and Mitigation of Carbon Footprint for Selected Developing and Developed Nations
}

\section{Pratibha Rai}

University of Delhi

Priya Gupta ( $\nabla$ pgupta1902@gmail.com )

Jawaharlal Nehru University https://orcid.org/0000-0002-4666-4203

Neha Saini

Netaji Subhas Institute of Technology: Netaji Subhas University of Technology

\section{Research Article}

Keywords: EKC hypothesis, Green and sustainable energy, CO2 Emissions, GDP, and economic indicators

Posted Date: October 21st, 2021

DOI: https://doi.org/10.21203/rs.3.rs-890359/v1

License: (1) This work is licensed under a Creative Commons Attribution 4.0 International License.

Read Full License 


\section{Evidence of Renewable Energy Use and Mitigation of Carbon Footprint for Selected Developing and Developed Nations}

4

\author{
Pratibha Rai ${ }^{1}$, Priya Gupta ${ }^{2}$, Neha Saini ${ }^{3}$
}

${ }^{1}$ Maharaja Agrasen College, University of Delhi, Delhi, India ${ }^{2}$ Atal Bihari Vajpayee School of Management and Entrepreneurship, Jawaharlal Nehru University, Birsa Munda Marg, JNU Campus Road, New Delhi, India

${ }^{3}$ Netaji Subhas University of Technology, New Delhi, Delhi

${ }^{1}$ rai.pratibha@gmail.com, ${ }^{2}$ pgupta1902@gmail.com, ${ }^{3}$ neha.saini@ nsut.ac.in 


\title{
Evidence of Renewable Energy Use and Mitigation of Carbon Footprint for Selected Developing and Developed Nations
}

\begin{abstract}
The focus of this paper is to investigate whether carbon footprints ${ }^{1}$ are reduced due to renewable energy use in fuelling the business and commercial interests of the nation's right from trade, production, consumption in the presence of foreign direct investment (FDI). The quantification of the relationship is carried out for three developed nations and five developing nations. Error Correction Model (ECM) using Autoregressive distributed lag (ARDL) ${ }^{2}$ methodology is used to assess short-term and long-term country-wise parameters for the chosen variables in sample countries from 1990 to 2017. The findings demonstrate the persuasive evidence that green energy use is the sustainable path of development. The cointegrated relationship amongst the variables for the long run is validated for all eight individual countries included in the study. High-economic growth and non-renewable energy use are recognized as the major sources of environmental degradation across the country analysis. However, the panel data series of eight countries did not support the analysis in the ARDL framework, hence the Random effect model and Granger Causality technique is used to quantify the magnitude and direction of association that exists between carbon emissions, renewable energy in the presence of other macroeconomic variables including square of GDP per capita (included to test EKC behaviour) respectively. In the presence of renewable energy resource as an influencer of carbon emissions, the overemphasized EKC hypothesis, however, is not supported in the panel data analysis and in country wise analysis.
\end{abstract}

Keywords: EKC hypothesis, Green and sustainable energy, $\mathrm{CO}_{2}$ Emissions, GDP, and economic indicators.

\section{Introduction}

The nations across the globe are driven by the objective of accelerated economic growth leading to increased energy consumption causing high carbon emissions and persistent environmental degradation (Apergis and Tang, 2013; Baranzini et al., 2013). The fact that the wave of globalization has hastened economic growth across both developing and developed countries cannot be disputed. Globalization has also nurtured technology transfers, cross-border flow of investments, and trade openness. The flip side of the story is the emergence of ensuing challenges in achieving wellbeing with sustainable development and arresting global warming (Dasgupta, S., Laplante, B., Wang, H., \& Wheeler, D. 2002; Özdemir, Özlem., \&Özokcu, Selin, 2017). The close link between economic growth, green and non-green energy use, and pollution caused due to carbon emissions during the business and economic processes that goes on in countries unabated and the impact of FDI inflows and trade-flows hasbeen the matter of interest inthe environmental and economic literature. The studies focussing on this aspect have produced sometimes ambiguous and controversial results (Paul and Benito, 2018; Klieret al., 2017; Fetscherin et al., 2010). The spread of globalization has indubitably been an engine of growth and advancement (Buckley and Casson, 2009; Perkins and Neumayer, 2008; Chan et al., 2006; Blonigen, 2005; Meyer, 2004;

\footnotetext{
${ }^{1}$ Carbon footprint term is used in this paper to represent carbon emissions

${ }^{2}$ ARDL -A model that permits a dependent variable to depend on current and past values of predictor variables and on its own past values which is autoregressive part. The lags can have a non-uniform distributed lag.
} 
93 Gray, 2002; Wheeler, 2001; Talukdar and Meisner, 2001) but it has also created substantial 94 challenges for ongoing sustainable development (Jorgenson, 2007; Hoffmann, Lee, Ramasamy, and Yeung, 2005). Post -World War II the most detrimental global event has been the Covid

96 pandemic adversely affecting millions of people across the world.

The revisit on the subject reiterates the requisite effort towards energy innovation that meets the environmental sustainability norm via the technique effect(Eskeland and Harrison, 2003; Cole et al., 2008). The initial structural change in the structure of the economy from subsistence agrarian to more energy-intensive industrial economy accompanies an increase in the pollution levels.

101 However, pollution decreases when the economic structure progresses towards light manufacturing and tertiary sector growth via the composite effect (A lvarez, Balsalobre and Cantos, 2015; Pao and Tsai, 2010, Liang and Teng 2006; Grossman and Krueger, 1995, 1991). Studies by Stokey (1998), Bergh and Nijkamp (1994) and Gradus and Smulders (1993), emphasized that sustainable development is possible through the stringent institutional framework and innovative techniques facilitated by the FDI policy. Pursuance of higher scale of production with minimal change in the technology and the economic structure of the economy, adversely affects environmental quality, and hastens the environmental degradation (Alvarez-Herranz et al., 2017). This study tries to validate that there exists a sustainability nexus between developing and developed countries through innovative infusion of green energy by adopting customised policies at country-level. FDI-CO $\mathrm{CO}_{2}$ interlinkage controlling the institutional factors, trade openness, and state of financial progress as a control variable has been studied to find the technique, scale, and composite effects (Singhania and Saini, 2021; Shao 2018; Neumayer 2009) across advanced and developing countries. Empirical studies endorse the relationship that exists amongst environmental pollution and income levels validating the EKC impact (Copeland and Taylor, 2004; Dinda, 2004; Dasgupta, et. al, 2002). However, Stern (2004) has questioned this hypothesis. There have been few studies that have included the renewable energy use in the model specification primarily focussing on country wise analysis because the time span of availability of renewable energy is short. From 1990 onwards, published data on RE usage (as a proportion of total final energy consumption) can be accessed as World Development Indicators (WDI). However, Sharif et al. (2019) attempted panel study to investigate the association of dynamics of non-renewable and renewable energy consumption with carbon emissions. Given the vast scope of the subject of unearthing associations amongst macro-economic variables linked to carbon emissions, different types of use of renewable and non-renewable energy, each country's perspective has not been thoroughly explored in the previous studies. Hence, an attempt is being made to enrich the literature on the subject through this empirical engaging quantitative research. The study emphasesthe nexus between $\mathrm{CO}_{2}$ emissions, oil energy usage, per capita GDP, GDP ${ }^{2}$, trade, green energy, and FDI in sample developed and developing countries.

The rest of the paper is structured in lined, where the stylised facts emerging from current literature are presented in section 2 . The theoretical and conceptual underpinnings are detailed in Section 3. The methodological viewpoint and empirical modelling are highlighted in section 4 . Section 5 is presenting the comprehensive empirical analysis, subdivided into six subsections. In section 6 discussions and findings are summarised.Conclusion in the light of data limitations and final wrap up in the form of scope for further research is presented as matters arising from this research devoted to unravelling the insinuations of the study in section 7 and 8 .

\section{Review of Existing Literature}

The nexus between the environmental degradation-GDP-energy are intertemporal in nature and its relevance for ensuring sustainability cannot be refuted in the studies of ecological and 
142 environmental economics. Saboori and Sulaiman (2013); Jayanthkumaran et al. (2012); Ghosh 143 (2010); Tamazian and Rao (2010); Narayan et al. (2010); Claessense and Feijen (2007); Feridun et 144 al. (2006); Tedesse (2005) have looked at the association between GDP, energy use, and $\mathrm{CO}_{2}$ emissions. Ghosh (2010) used the Johansen- Juselius maximum likelihood process and ARDLbound testing technique to investigate the causal association among environmental degradation and economic growth. The EKC hypothesis was found to be true by Jayanth Kumaran et al. (2012), although the link between structural changes and carbon emissions was not found to be substantial. Birdsall and Wheeler (1993) study the promotion of trade liberalization towards the reduction of $\mathrm{CO}_{2}$ while World Bank (2000), Jensen (1996), andShahbaz et al. (2013) pinpoints trade to be a culprit for emission intensity. Empirical findings are conflicting with respect to the link between FDI and pollution concentration. Tedesse (2005) emphasized on the importance of financial development that spurs technological innovations resulting in higher productivity. FDI affects the ecological environment of host country either in the form of "pollution haven" or as "pollution halo" hypothesis. The pollution halo hypothesis widely talked about in the literature (Mert M., \&Cağlar A.E, 2020;Sun C,\&Zhang F, Xu M2017) is the result of stringent environmental standards and laws in host countries faced by the global and multinational companies possessing state of the art technology and managerial practices (Zarsky, 1999). Multinational companies whose organic growth is under high governance standards and environmental practices (Saini and Singhania, 2018; Singhania et al., 2015) have the potential to transform the processes leading to the environmental damages to environmental sustenance. Multinational companies, that completely lose sight of the environmental protection of host countries and are only governed by economic parameters of profit-making are responsible for the pollution haven hypothesis (Perkins and Neumayer, 2008; Gray, 2002; Talukdar and Meisner, 2001). The most polluting industries are being relocated to the developing world due to the prevalence of relatively lower carbon taxation/fee and implementation costs in these countries often signalling lower environmental values causing further worsening of the environment (Copeland and Taylor, 1994; Chichilnisky, 1994).

There is a need for policy reforms and effective global agreements to mitigate GHGs emissions. A range of environmental initiatives has been used by the OECD countries to achieve sustainable business objectives (SDGs) (OECD, 2011). Developing countries, often lag in introducing and implementing regulatory environmental norms although they are more vulnerable to environmental degradation. National and regional environmental policy reforms are needed, but they must also be strictly implemented in order to stay up with the changing global reality and maintain the sustainability ethos.

Lee (2019) examines the changing aspects of RE, emissions of $\mathrm{CO}_{2}$ and GDP for the long andshort run in European Union using VECM. The findings of the research convey that the longrun dynamics from endogenous variables to $\mathrm{CO}_{2}$ emissions are both negative and significant. This points to the European Union's energy and environmental policies' long-term effectiveness in reducing $\mathrm{CO}_{2}$ emissions. Sharif et al., (2019) have sought to analyse the dynamic link between $\mathrm{NRE}$ and $\mathrm{RE}$ usage in order to evaluate the influence on $\mathrm{CO}_{2}$ emissions through panel analysis. Nguyen and Kakinaka (2019) considering the data of 107 nations from 1990 to 2013 studies the association of $\mathrm{RE}$ and NREusage on $\mathrm{CO}_{2}{ }^{3}$ between high- and low-income countries. The longrun impact of RE consumption and output on carbon emissions essentially relates to the country's development stage. The results exhibit consistency with the EKC hypothesis. In addition to minimising the detrimental effects of global warming, reduced $\mathrm{CO} 2$ emissions also create an ecofriendlier environment. It is also essential that fossil fuels are replaced by green technology as the primary energy source, according to Razmjoo and colleagues (2020). While Apergis et al.,

${ }^{3}$ Carbon emission and $\mathrm{CO}_{2}$ have been used interchangeably in this paper. 
190 (2018), discovered bidirectional causality between $\mathrm{CO}_{2}$ emissions and $\mathrm{RE}$ in short run resutls.

191 Causality running in one direction was found to be moving from renewable energy consumption to expenditure on wellbeing.

\section{Methodology and Econometric Modelling}

The study aims to determine the direction of the association between predictor variables, and also unravel the overall impact on carbon emissions by including renewable energy in the presence of specific macro-economic variables that influence the relationship. In the light of the broad objective stated above, the three sub-objectives were identified: (1) to observe if there is a long run cointegrating association amongst factors that influence carbon emissions (2) to study and evaluate the outcome of renewable energy on carbon emissions to highlight complex interactions amid environmental pollution and economic growth. (3) to analyse some significant directional associations amongst the variables across nations, given the complexity and uniqueness of developing and developed countries. (4) to revisit the Environmental Kuznets Curve (EKC) postulate.

The EKC hypothesis supports the argument that sustainable development is feasible if nations continue to grow and fund environmental improvement later. In fact, the real-world outcomes are not reflected by this postulate. It needs to be acknowledged by the humanity that there are limits to growth and these thresholds are set by the carrying capacity of the nature. The biodiversity loss is irreversible (Prieur, Fabien, 2009; Karsch, 2019). Mills and Waite (2009) effectively present in their study that monetary and economic growth and conservation of biodiversity are not compatible ends. In this research, the intent is to re-emphasize that the nations must revert to sustainable energy options for meeting growth objectives best suited as per the topography, location, and available natural resources within the bounds of the countries. (Colantonio, \&Gattone., 2020).As a result, environmental laws must be strengthened in order to enhance the integrity of the ecosystem and to establish policies that encourage the use of renewable energy and the conservation of the natural world. The present study hence approaches to explore linkage between $\mathrm{CO}_{2}$ and green energy along with the macro-economic variables like GDP, FDI, trade openness and NRE consumption (oil energy) from country perspective to validate the research intent. The country-wise analysis is subjected to panel estimation as well to see the linkagein the pooled data series. Following are the hypothesis of the study:

Hypothesis1: $\mathrm{CO}_{2}$ and economic variables have a long run cointegrating relationship

226 Hypothesis 2: Overemphasis is placed on the existence of the inverted U-shaped EKC hypothesis

227 Hypothesis 3: Emissions of $\mathrm{CO}_{2}$ and NRE have a positive and strong relationship.

228 Hypothesis 4: The direction of the relationship between $\mathrm{RE}^{4}$ use and $\mathrm{CO}_{2}$ are negative.

\subsection{Data Description}

${ }^{4}$ Renewable energy and green energy have been used interchangeably in this paper. 
231 The variables, oil energy, GDP, GDP ${ }^{2}$, Trade, Green energy (renewable energy), Foreign Direct

232 Investment (FDI) were identified to be determinants impacting the Carbon emissions $\left(\mathrm{CO}_{2)}\right.$ as per the reviewed literature.

$$
\begin{aligned}
\mathrm{CO}_{2 t}= & \beta_{0}+\alpha_{1} \text { Oil Energy }_{t}+\alpha_{2} G D P_{t}+\alpha_{3} G D P^{2} t+\alpha_{4} \text { Trade }_{t}+\alpha_{5} \text { Green Energy }_{t} \\
& +\alpha_{6} \text { FDI }_{t}+\varepsilon_{t}
\end{aligned}
$$

238 where $\varepsilon$ denote error, $\mathrm{t}$ indicates time

$239 \mathrm{CO}_{2 t}$ is quantified in metric tonnes per capita and it is an environmental degradation indicator

240 Oil Energy shows use of $\mathrm{kg}$ of oil equivalent per capita reflecting energy consumption

$241 G D P_{t}$ is measured in local constant local currency unit indicating real GDP per capita $G D P_{t}^{2}$ represents square of the real GDP per capita which isused forcapturing EKC effect Tradet reflects Trade Openness in country at time $\mathrm{t}$.

$244 \quad F^{2} I_{t}$ represents Foreign Direct Investment

245 Green Energy ${ }_{t}$ indicates renewable energy (\% of total final energy-use). $F D I_{t}$ represents Foreign Direct Investment

For the variables listed in equation (1) data is obtained from WDI for 27 years from 1990 to 2017 for sample 20 countries. The ARDL technique assumes that all variables are endogenous.

250 According to (Pesaran and Shin, 1999), in the ARDL approach both regressors and regressand are fed in the system with lags and this augmentation takes care of the possibility of endogeneity of regressor. ARDL scores over the other techniques such as the one suggested by Engle and Granger (1987), another by Johansen and Juselius (1990) known as cointegration techniques. The power of ARDL rests on the premise that (a) it can be applied on I(0) or I(1) or a combination of both (b) it can be applied on a small data set, (c) it can be applied even when model regressor suffers from endogeneity. The bound testing approach in general provides valid $t$ statistics for long run unbiased estimates (Narayan, 2005). (d) ECT is derived in ARDL via simple linear transformation integrating short-run adjustment within the long run equilibrium with no loss of evidence pertaining to long period. (Pesaran and Shin, 1999). CUSUMSQ was used to check the stability of the long-term parameters as proposed by (Pesaran and Shin, 1999). Other diagnostic checks are also performed and reported in the section devoted to the analysis of results.

The EU EDGAR database ${ }^{5}$ was used to select the samplecountries considered to be major carbon emitters in the world. The framework of the study initially involved targeting 20 most polluting developed and developing countries and the current data available on the WDI on the World Bank $^{6}$ website was used. The analysis was limited to 8 developed and developing countries for the period 1990 -2019 since some of data series like oil energy, $\mathrm{CO}_{2}$ emission and renewable energy series were found to be I (2) for some nations. The missing values in individual data series were carefully examined for each country and were interpolated and extrapolated based on trend line assessment after careful examination. Hence, given this constraint of data, the current paper covers analysis of five developing countries viz Argentina Brazil, Iran, South Africa, Mexico and three developed countries viz. Germany, Poland, Canada. However, for Iran, South Africa, Mexico the proxy variable was chosen for per capita real GDP (computed in constant domestic currency) since it was found to be I(2). GDP constant (measured in local constant currency) was used instead. Renewable energy (\% of total energy) was found to be I(2) for Iran and South Africa so alternative variable chosen is combustible renewables and waste ( $\%$ of total energy). The

\footnotetext{
${ }^{5}$ EDGAR is an independent, multipurpose, global database of emissions of greenhouse gases and air pollution on Earth primarily due to anthropogenic interventions. https://worldpopulationreview.com/country-rankings/pollution-by-country ${ }^{6}$ https://databank.worldbank.org/source/world-development-indicators
} 
countries like Argentina and Brazil and Germany for which the nature of the data series did not pose a challenge, ARDL technique was applied on the original series as indicated in the description of equation (1) and (2) for understanding the long run and short run dynamic linkage spanning over 1990-201. However, at country level across five developing and three developed countries the short run and long run association was observed to be largely stable.

The choice of a relatively smaller data frame is contingent upon the fact that the data for renewable energy use across nations is available as World Development Indicator from 1990 onwards. The analysis could be conducted only for five countries of the developing world comprising of Argentina, Brazil, Iran, South Africa, and Mexico and three countries of the developed world comprising of Germany, Poland, Canada using the ARDL technique due to data issues. It is pertinent to mention that there did not seem to be a good proxy variable for $\mathrm{CO}_{2}$ emission measured in metric tonnes per capita and for energy consumption ( $\mathrm{kg}$ of oil equivalent per capita) hence all those countries whose data series were at $\mathrm{I}(2)$ with respect to these series were dropped from the analysis. Anotherforced reason for dropping countries from the analysis is that given the short time frame the problem of near singular matrix was cropping up while attempting the analysis in the ARDL framework. The review of literature (Mert\&Bölük, 2016, Saini \& Sighania, Ozturk, I., 2010) shows that the analysis in the ARDL framework with the considered variables has been attempted by the researchers. The longer time frame of analysis resolves such modelling issues. Hence, 12 top polluting countries could not be covered in the analysis.

Panel data analysis was also run on these eight countries to understand the general direction of association amongst the variables. It is pertinent to mention here that the variables chosen for conducting the panel analysis are uniform across countries and are as described beneath equation 1 except one data series i.e., renewable energy. The data series considered for panel analysis are $\mathrm{CO}_{2}$ as an environmental degradation indicator, Oil Energy, GDP, GDP ${ }^{2}$ represents square of per capita real GDP which isused forcapturing EKC effect. These data series were found to be I(1). While FDI,Trade Openness in country were found to be $\mathrm{I}(0)$. The panel series green energyindicating RE (\% of total final energy-use) was found to be $\mathrm{I}(2)$ hence a proxy renewable energy series representing combustible renewable and waste (\% of total energy) was chosen to further the analysis. However, the panel data series of eight countries did not support the analysis in the ARDL framework, hence the random effect model is used for panel estimation.

310

\subsection{Model Specification}

ARDL involves estimation of the following relationship amongst the variables.

$$
\Delta C O_{2 t}=\beta_{0}+\sum_{i=o}^{p} \beta_{1 i} \Delta C O_{2 t-i}+
$$

$$
\begin{aligned}
& \sum_{i=o}^{p} \alpha_{1 i} \Delta \text { Oil energy }_{t-i}+\sum_{i=o}^{p} \alpha_{2 i} \Delta G D P_{t-i}+\sum_{i=o}^{p} \alpha_{3 i} \Delta G D P_{t-i}^{2}+ \\
& \sum_{i=o}^{p} \alpha_{4 i} \Delta \text { Trade }_{t-i}+\sum_{i=o}^{p} \alpha_{5 i} \Delta \text { Green energy }_{t-i}+\sum_{i=o}^{p} \alpha_{6 i} \Delta F D I_{t-i}+E_{1} C O_{2 t-i}+ \\
& \lambda_{1} \text { Oil energy }_{t-i}+\lambda_{2} G D P_{t-i}+\lambda_{3} G D P^{2}{ }_{t-i}+\lambda_{4} \text { Trade }_{t-i}+\lambda_{5} \text { Green Energy }_{t-i}+ \\
& \lambda_{6} F D I_{t-i}+\mu_{\mathrm{t}}
\end{aligned}
$$

Where $\Delta=$ change after first differencing, 
$\mu_{\mathrm{t}}=$ noise residuals $\mathrm{CO}_{2}$,

324 Oil energy, green energy, FDI, Trade, GDP, SQGDP, have been defined in the first equation. $\Sigma$ represents the dynamics of error correction and $\lambda$ i signifies the long-run association. The timerelated trend variables are incorporated to grasp the autonomous changes that are time-related.

In next phase the estimation of the ECM is initiated if long-term association amongst the variables is validated as per equation 2 .

$$
C O_{2 t}=\beta_{0}+\sum_{i=o}^{p} \beta_{1 i} \Delta C O_{2 t-i}+
$$

The speed of adjustment is captured by $\eta$ which represents the equilibrium restored in the system when shock occurs. ECT $\mathrm{E}_{\mathrm{t}-1}$ is the residual series obtained after the estimation of the Equation 1 representing cointegration model. The F-statistics value is dependent on the lags selected based on Schwarz-Bayesian information (SIC) or Akaike information (AIC) Pesaran et al. (2001). the coefficients of the time varying variables of the observed and latent time-invariant variables do not change over time respectively for all $t$, that the equation error variances are equal and the disturbance in a cross-section is uncorrelated with the observed explanatory variables. The benefit of using REM is that the time-invariant omitted variables are controlled (Bollen and Brand, 2010).

$$
\text { Random Effect model for Estimating Panel Data }
$$

$$
\begin{aligned}
\mathrm{CO}_{2 i t}= & \beta_{0}++\beta 1 C O 2_{i t-1} \alpha_{1} \text { Oil Energy }_{i t}+\alpha_{2} G D P_{i t}+\alpha_{3} G D P^{2} i t+\alpha_{4} \text { Trade }_{i t}+\alpha_{5} \text { Green Energy }_{i t} \\
& +\alpha_{6} \mathrm{FDI}_{i t}+\omega_{i t}
\end{aligned}
$$

where $\omega_{i t}=v_{i t}+\varepsilon_{i}$ subscript shows no. of cross sections while $t$ shows time $\varepsilon_{i}$ is a measure of the random deviation of each entity's constant term from the "global" intercept term $\alpha$. There is no need for a dummy variable to take care of the heterogeneity in the crosssectional dimension.

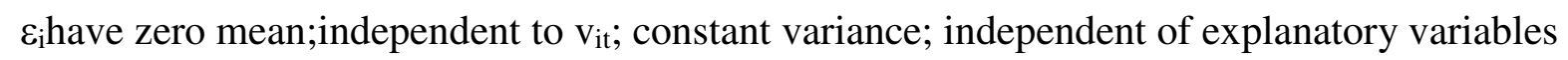

\begin{tabular}{|c|c|c|c|c|c|c|c|c|c|}
\hline Country & & Argentina & Brazil & Iran & Mexico & South A & Canada & Poland & German \\
\hline \multirow{2}{*}{ Carbon } & Level & -1.11 & -1.19 & -35 & 0.45 & -2.23 & -0.81 & -2.22 & -1.31 \\
\hline & First & $-4.61 * *$ & $-3.32 * *$ & $-5.45 * *$ & $-5.092 * *$ & $-5.62 * *$ & $-3.48 * *$ & $-5.15 * *$ & $-7.73 * *$ \\
\hline \multirow{2}{*}{ Oil Energy } & Level & -0.5 & -2.18 & -0.35 & -1.73 & -1.48 & 0.77 & -1.32 & -1.52 \\
\hline & First & $-5.10 * *$ & $-6.51 * *$ & $-5.75 * *$ & -4.47 & $-4.43 * *$ & $-3.92 * *$ & $-5.35 * *$ & $-6.10 * *$ \\
\hline GDP & Level & -1.89 & -0.86 & -1.19 & -1.15 & -0.69 & -0.167 & $-1.47 * *$ & 0.61 \\
\hline
\end{tabular}
GLS estimation is done since OLS is consistent but inefficient

\section{Analysis of Results}

Table 1: Results of Unit Root Test using ADF Methodology 


\begin{tabular}{|c|c|c|c|c|c|c|c|c|c|}
\hline & First & $-4.15 * *$ & $-3.65 * *$ & $-4.71 * *$ & $-5.75 * *$ & $-3.06 * *$ & $-4.44 * *$ & $-3.65 * *$ & $-6.68 * *$ \\
\hline \multirow{2}{*}{ GDP $^{2}$} & Level & -1.67 & -1.07 & -1.12 & -0.99 & -0.19 & 0.964 & -1.39 & 1.13 \\
\hline & First & $-4.40 * *$ & $-3.53 * *$ & $-4.77 * *$ & $-5.60 * *$ & $-3.11 * *$ & 0.002 & $-3.05 * *$ & $-6.56 * *$ \\
\hline \multirow{2}{*}{ Trade } & Level & -2.47 & -2.03 & -1.06 & -0.94 & -2.58 & -2.13 & -0.38 & -0.6 \\
\hline & First & $-4.20 * *$ & $-5.84 * *$ & $-4.39 * *$ & $-6.31 * *$ & $-4.89 * *$ & $-3.48 * *$ & $-5.14 * *$ & $-5.12 * *$ \\
\hline \multirow{2}{*}{ Green energy } & Level & -2.38 & -2.34 & -1.83 & -1.29 & -1.77 & -0.86 & -0.9 & 1.522 \\
\hline & First & $-4.70 * *$ & $-3.13 * *$ & $-4.70 * *$ & $-6.61 * *$ & $-4.18 * *$ & $-5.21 * *$ & $-4.56 * *$ & $-4.58 * *$ \\
\hline \multirow{2}{*}{ FDI } & Level & $-3.93 * *$ & -1.36 & -1.88 & 0.544 & $-3.461 * *$ & $-4.48 * *$ & $-3.43 * *$ & $-3.75^{* *}$ \\
\hline & First & ---- & $-5.88 * *$ & -4.51 & $-8.35 * *$ & ---- & ---- & ---- & ---- \\
\hline
\end{tabular}

** Stationarity significant at 0.05

364

365

366

367

368

369

370

371

372

373

\subsection{Stationarity}

It is important to check stationarity property of variables for estimating a long-term relationship. The unit root test is applied to find out if shocks of any kind have some permanent effect which do not subside. If unit root problem is found in the series, detrending the series is a must for carrying further analysis. All considered variable series for model estimation was found to be I(1) for Brazil, Iran, and Mexico. While for Argentina, South Africa, Canada, Poland and Germany all series are I(1) except Foreign Direct Investment which was found to be I(0).

Table 2: Panel A- Long-Run Estimation for Sample Countries

\begin{tabular}{|c|c|c|c|c|c|c|c|c|}
\hline & \multicolumn{5}{|c|}{ Developing Countries } & \multicolumn{3}{|c|}{ Developed Countries } \\
\hline Variables & Argentina & Brazil & Iran & Mexico & $\begin{array}{l}\text { South } \\
\text { Africa }\end{array}$ & Canada & Poland & Germany \\
\hline $\mathrm{C}$ & $\begin{array}{l}1.672^{*} \\
(2.101)\end{array}$ & $\begin{array}{l}1.543^{* *} \\
(2.358)\end{array}$ & $\begin{array}{l}3.484 \\
(0.4654)\end{array}$ & $\begin{array}{l}-10.779 * * \\
-(3.898)\end{array}$ & $\begin{array}{l}13.32 \\
(1.688)\end{array}$ & $\begin{array}{l}3.425 \\
(1.424)\end{array}$ & $\begin{array}{l}-11.617 * * \\
(-3.322)\end{array}$ & $\begin{array}{l}18.631 \\
(1.479)\end{array}$ \\
\hline $\mathrm{CO}_{2}(-1)$ & $\begin{array}{l}-0.084 \\
(-0.94)\end{array}$ & $\begin{array}{l}0.192 \\
(1.593)\end{array}$ & $\begin{array}{l}3.78 * * \\
(2.204)\end{array}$ & $\begin{array}{l}0.236 * * \\
(2.087)\end{array}$ & $\begin{array}{l}-0.59 * * \\
(-2.72)\end{array}$ & $\begin{array}{l}0.6595 * * \\
(4.093)\end{array}$ & $\begin{array}{l}0.083235 \\
(0.862)\end{array}$ & $\begin{array}{l}0.542 * * \\
(2.22)\end{array}$ \\
\hline $\begin{array}{l}\text { Oil Energy } \\
\text { Oil Energy (-1) }\end{array}$ & $\begin{array}{l}0.0019 \text { ** } \\
(6.563)\end{array}$ & $\begin{array}{l}0.002 * * \\
(8.47)\end{array}$ & $\begin{array}{l}0.00252 * * \\
(4.325)\end{array}$ & $\begin{array}{l}0.002 * * \\
(5.846)\end{array}$ & $\begin{array}{l}0.0042 * * \\
(2.205)\end{array}$ & $\begin{array}{l}0.049 * * \\
(2.13) \\
0.069 * * \\
(2.747)\end{array}$ & $\begin{array}{l}0.0447 * * \\
(8.022)\end{array}$ & $\begin{array}{l}0.1087 *= \\
(7.69) \\
-0.086 \\
(-2.870)\end{array}$ \\
\hline $\begin{array}{l}\text { GDP } \\
\text { GDP (-1) }\end{array}$ & $\begin{array}{l}-9.10 \mathrm{E}-06 \\
(-0.090)\end{array}$ & $\begin{array}{l}6.73 \mathrm{E}-05 \\
(0.622) \\
-0.0001 \\
(-1.578)\end{array}$ & $\begin{array}{l}-1.36 \mathrm{E}-07 \\
(-0.900)\end{array}$ & $\begin{array}{l}0.00015 * * \\
(3.56)\end{array}$ & $\begin{array}{l}-0.002 \\
(-0.894) \\
0.00015^{* *} \\
(2.331)\end{array}$ & $\begin{array}{l}0.0005 \\
(1.715)\end{array}$ & $\begin{array}{l}1.72 \mathrm{E}-11 * * \\
(4.87)\end{array}$ & $\begin{array}{l}6.87 \mathrm{E}-0 . \\
(0.148) \\
-0.00097 \\
(-2.134)\end{array}$ \\
\hline $\begin{array}{l}\mathrm{GDP}^{2} \\
\mathrm{GDP}^{2}(-1)\end{array}$ & $\begin{array}{l}5.77 \mathrm{E}-10 \\
(0.169)\end{array}$ & $\begin{array}{l}-3.13 \mathrm{E}-09 \\
(-0.963) \\
4.47 \mathrm{E}-09 \\
(1.5057)\end{array}$ & $\begin{array}{l}7.59 \mathrm{E}-16 \\
(0.436)\end{array}$ & $\begin{array}{l}-6.21 \mathrm{E}-10 * * \\
(-3.42)\end{array}$ & $\begin{array}{l}3.619 \mathrm{E}-10 \\
(0.147)\end{array}$ & $\begin{array}{l}-5.90 \mathrm{E}-09 \\
(-1.25) \\
-2.37 \mathrm{E}-09^{*} \\
(-1.972)\end{array}$ & $\begin{array}{l}-4.42 \mathrm{E}-24 * * \\
(-2.525) \\
-1.16 \mathrm{E}-24 * \\
(-1.821)\end{array}$ & $\begin{array}{l}3.26 \mathrm{E}-09 \\
(0.604) \\
9.33 \mathrm{E}-09 \\
(1.749)\end{array}$ \\
\hline $\begin{array}{l}\text { Trade } \\
\text { Trade (-1) }\end{array}$ & $\begin{array}{l}1.0410 \\
(1.711)\end{array}$ & $\begin{array}{l}-0.606 \\
(-0.908)\end{array}$ & $\begin{array}{l}2.016 \\
(1.433)\end{array}$ & $\begin{array}{l}0.169 \\
(0.294)\end{array}$ & $\begin{array}{l}2.414^{*} \\
(1.798)\end{array}$ & $\begin{array}{l}0.027 * \\
(2.141)\end{array}$ & $\begin{array}{l}0.0058 \\
(0.5773)\end{array}$ & $\begin{array}{l}-0.0088 \\
(-0.707) \\
0.0199 \\
(1.643)\end{array}$ \\
\hline $\begin{array}{l}\text { Green energy } \\
\text { Green energy }(-1)\end{array}$ & $\begin{array}{l}-0.053^{* *} \\
(-4.45) \\
-0.038^{* *} \\
(-2.469)\end{array}$ & $\begin{array}{l}-0.0375 * * \\
(-8.755) \\
0.0120 \\
(1.675)\end{array}$ & $\begin{array}{l}-1.733 * * \\
(-2.40)\end{array}$ & $\begin{array}{l}0.038 \\
(0.478)\end{array}$ & $\begin{array}{l}-0.27 \\
(-0.472) \\
-0.88 * * \\
(-2.644)\end{array}$ & $\begin{array}{l}-0.218 \\
(-0.52)\end{array}$ & $\begin{array}{l}-0.031 \\
(-0.903) \\
.0696^{*} \\
(2.128)\end{array}$ & \begin{tabular}{l|}
0.0277 \\
$(0.541)$ \\
$-0.154 * *$ \\
$(-2.332)$
\end{tabular} \\
\hline $\begin{array}{l}\text { FDI } \\
\text { FDI (-1) }\end{array}$ & $\begin{array}{l}7.52 \mathrm{E}-12 \text { ** } \\
(2.692)\end{array}$ & $\begin{array}{l}3.41 \mathrm{E}-13 \\
(0.776)\end{array}$ & $\begin{array}{l}8.80 \mathrm{E}-12 \\
(0.14)\end{array}$ & $\begin{array}{l}-1.25 \mathrm{E}-12 \\
(-0.59)\end{array}$ & $\begin{array}{l}-5.11 \mathrm{E}-11 * * \\
(-2.663) \\
-4.30 \mathrm{E}-11 * * \\
(-2.908)\end{array}$ & $\begin{array}{l}0.036 \\
(1.002)\end{array}$ & $\begin{array}{l}0.0049 \\
(0.626)\end{array}$ & $\begin{array}{l}-0.002 \\
(-0.253)\end{array}$ \\
\hline
\end{tabular}




\begin{tabular}{|l|l|l|l|l|l|l|l|l|}
\hline $\mathrm{R}^{2}$ & 0.9518 & 0.9983 & 0.988 & 0.9526 & 0.964 & .9329 & .9797 & 0.9948 \\
\hline Adjusted R & & & & & & & & \\
& 0.9496 & 0.9970 & 0.982 & 0.9319 & 0.937 & .8916 & .9657 & 0.9880 \\
\hline F Statistic & ---- & 788.256 & 190.51 & 45.96 & 35.70 & ------ & 69.84 & 145.32 \\
\hline Durbin Watson & 1.866 & 2.610 & 2.188 & 2.061 & 2.461 & 2.659 & 2.004 & 2.900 \\
\hline
\end{tabular}

* Significant at $0.1 \quad$ ** Significant at 0.05

375 Note: Corresponding t values associated with coefficients are shown in bracket (Table 2).

\subsection{Long Run Analysis}

The outcomes of estimates of equation 2 are mixed. Previous year carbon emissions are found to be statistically significant contributing towards current year carbon emissions in Iran, Mexico, Canada, and Germany. Oil energy's influence in adversely impacting the environment is statistically significant across all eight countries is aligned to environmental truism. The positive coefficient of GDP was estimated for five countries, but it was found significant for Mexico and Poland supporting the hypothesis of scale effect leading to environmental degradation (AlvarezHerranz, Balsalobre, Cantos, and Shahbaz, 2017). The negative sign of GDP ${ }^{2}$ seems to support EKC hypothesis across four nations but it was found to be significant only for Mexico and Poland, but the magnitude is abysmally low. There is a purpose behind retaining these weak exponential coefficients in the table to highlight the same. EKC hypothesis is not supported in this study. The influence of green energy on carbon emissions is found negative for all countries except Mexico and significant for Argentina, Brazil, Iran in the category of developing countries for current period and significant for South Africa, Poland, and Germany for one period lag. However, for Canada the relationship is negative but not significant between green energy and carbon emissions. These results are indicative of the fact that green energy usage is positively linked to lessening the environmental degradation across six countries and the strength of association is noteworthy. The direction of Impact of trade in reducing carbon emission was found desirable for two countries Brazil and Germany but was found to be significant at 0.05 only for Germany. For other six countries, the association of trade and $\mathrm{CO}_{2}$ emission was found to be positive but significant at $0.1 \%$ for Canada. Goodness of fit (Adjusted $\mathrm{R}^{2}$ ) of the ARDL model across all countries was found to be close or higher than $90 \%$. Durbin Watson results indicate absence of autocorrelation. Errors were found to be normally distributed except for Mexico. Absence of heteroscedasticity across all countries except Germany as indicated by Breusch Pagan Godfrey test. P values were found to be greater than 0.05. Test results of Breusch Godfrey LM test were also satisfactory except for Argentina.

Table 3: Short-Run Estimation for Sample Countries Dependent Variable :D $\left(\mathrm{CO}_{2}\right.$ Emissions $)$

\begin{tabular}{|c|c|c|c|c|c|c|c|c|}
\hline \multicolumn{6}{|c|}{ Developing Countries } & \multicolumn{3}{|c|}{ Developed Countries } \\
\hline Variables & Argentina & Brazil & Iran & Mexico & South Africa & Canada & Poland & Germany \\
\hline \multirow{2}{*}{$\begin{array}{l}\mathrm{D}(\mathrm{Oil} \\
\text { Energy) }\end{array}$} & $0.0020^{* *}$ & --- & --- & --- & --- & $0.049^{* *}$ & --- & $0.108^{* *}$ \\
\hline & $(15.97)$ & --- & --- & --- & --- & (3.43) & --- & $(15.97)$ \\
\hline \multirow{2}{*}{$\mathrm{D}(\mathrm{GDP})$} & $1.75 \mathrm{E}-05 * *$ & $6.73 \mathrm{E}-05$ & --- & & $2.9 \mathrm{E}-11^{* *}$ & $\begin{array}{ll}--- \\
--\end{array}$ & $-\overline{---}$ & $6.87 \mathrm{E}-05$ \\
\hline & $(3.154)$ & $(1.174)$ & -- & -- & $(7.99)$ & $-\cdots$ & --- & $(0.308)$ \\
\hline \multirow{2}{*}{$\mathrm{D}\left(\mathrm{GDP}^{2}\right)$} & $-1.29 \mathrm{E}-09$ & 3.13E-09 & --- & --- & $\begin{array}{c}--- \\
-1\end{array}$ & $-5.9 \mathrm{E}-09 * *$ & $-4.4 \mathrm{E}-24 * *$ & $3.26 \mathrm{E}-09$ \\
\hline & $(-0.847)$ & $(1.8063)$ & --- & ---- & ---- & $(-3.17)$ & $(-13.75)$ & $(-1.264)$ \\
\hline \multirow{2}{*}{$\mathrm{D}$ (Trade) } & --- & --- & --- & --- & --- & --- & --- & -0.008 \\
\hline & $-\cdots$ & --- & $-\cdots$ & $-\cdots$ & $-\overline{-}$ & $-\ldots$ & --- & $(-1.379)$ \\
\hline
\end{tabular}




\begin{tabular}{|l|l|l|l|l|l|l|l|l|}
\hline \multirow{2}{*}{$\begin{array}{l}\text { D (Green } \\
\text { Energy) }\end{array}$} & $-0.053 * *$ & $-0.0375 * *$ & --- & --- & $-0.277 *$ & --- & -0.031 & -0.027 \\
\cline { 2 - 9 } & $(-6.819)$ & $(-15.29)$ & --- & & $(-1.965)$ & --- & $(-1.598)$ & $(-1.182)$ \\
\hline \multirow{2}{*}{ D(FDI) } & --- & --- & --- & --- & $-4.8 \mathrm{E}-11 * *$ & --- & --- & --- \\
\cline { 2 - 9 } & --- & --- & --- & --- & $(-6.332)$ & --- & --- & --- \\
\hline \multirow{2}{*}{$\begin{array}{l}\text { ECT (-1) } \\
\text { term }\end{array}$} & $-0.932 * *$ & $-0.803 * *$ & $-0.62 * *$ & $-0.76 * *$ & $-0.923 * *$ & $-0.340 * *$ & $-0.916^{* *}$ & $-0.457 * *$ \\
\cline { 2 - 9 } & $(-16.189)$ & $(-14.17)$ & $(-5.890)$ & $(-11.44)$ & $(-9.9103)$ & $(-4.50)$ & $(-16.82)$ & $(-7.341)$ \\
\hline
\end{tabular}

\begin{tabular}{|l|l|l|l|l|l|l|l|l|}
\hline \multicolumn{2}{|l|}{ Model Fit and Diagnostics } \\
\hline $\mathrm{R}^{2}$ & 0.589 & 0.975 & 0.6119 & 0.8498 & 0.951 & 0.666 & 0.932 & 0.976 \\
\hline $\begin{array}{l}\text { Adjusted } \\
\mathrm{R}^{2}\end{array}$ & 0.527 & 0.971 & 0.5943 & 0.8498 & 0.9439 & 0.631 & 0.925 & 0.969 \\
\hline $\begin{array}{l}\text { Durbin } \\
\text { Watson }\end{array}$ & 1.9906 & 2.61 & 2.188 & 2.0619 & 2.58 & 2.659 & 2.004 & 2.900 \\
\hline $\begin{array}{l}\text { CUSUM } \\
\text { Normality } \\
\text { (p value) }\end{array}$ & $\begin{array}{l}\text { Stable } \\
\text { model }\end{array}$ & $\begin{array}{l}\text { Stable } \\
\text { model }\end{array}$ & $\begin{array}{l}\text { Stable } \\
\text { model }\end{array}$ & $\begin{array}{l}\text { Stable } \\
\text { model }\end{array}$ & $\begin{array}{l}\text { Stable } \\
\text { model }\end{array}$ & $\begin{array}{l}\text { Stable } \\
\text { model }\end{array}$ & $\begin{array}{l}\text { Stable } \\
\text { model }\end{array}$ & $\begin{array}{l}\text { Stable } \\
\text { model }\end{array}$ \\
\hline $\begin{array}{l}\text { BPGTest } \\
(p \text { value })\end{array}$ & 0.7603 & 0.8470 & 0.253 & 0.00004 & 0.8290 & 0.1592 & 0.4831 & 0.5483 \\
\hline $\begin{array}{l}\text { BG LM } \\
(p \text { value })\end{array}$ & 0.8616 & 0.9983 & .0919 & 0.3781 & 0.1042 & 0.0616 & 0.745 & 0.3196 \\
\hline
\end{tabular}

407 Note: Corresponding t values associated with coefficients are shown in bracket (Table 3).

\subsection{Short Run Analysis}

The parameters of Equation 3 were estimated using the ARDL cointegration procedure. The coefficients of level variables have been found using AIC criterion. Use of Akaike Information Criterion is considered parsimonious to estimate the coefficients of variables at level. This not only ensured to minimizing the loss of freedom but to get to the smallest lag length. (Boutabba, 2014). Table 3elaborates the estimated short-run results by country. NRE coefficient has a significant short-run positive influence on carbon emissions in Canada and Germany and Argentina, this entails increasing energy demand in tandem with increased economic activity, resulting in higher $\mathrm{CO}_{2}$ emissions. The coefficient estimates of GDP and $\mathrm{GDP}^{2}$ must be examined to evaluate the EKC hypothesis. The coefficient of $\mathrm{GDP}^{2}$ was found to be statistically significant for Canada and Poland but very weak, barely existent in terms of magnitude in the short run.

Coefficient of green energy was found negative and significant for Brazil and Argentina (significant at 0.05) and South Africa (significant at 0.1). These results are aligned with conclusions of Panayotou (1997) and Arrow (1995) and Nicole, M. K. (2019), that economic expansion is not a panacea for environmental health, rather switching to green ways of production and consumption across nations in reducing carbon emissions is convincingly validated in quantitative analysis. For South Africa, the coefficient of FDI is found to be negative and significant. ECT term signifies cointegration amongst variable series.Across all sampled countries, it is found to be statistically significant and negative, which is a notable finding. In Table 4 Bounds test results are presented and analysed. 
Diagnostics performed for each country model are presented in Table 4 and they are indicative of robust predictive power of the ARDL models.

Table 4: Bounds Test Results

\begin{tabular}{|c|c|c|c|}
\hline Sample country & Specification of ARDL Model & F-Bounds & Inference \\
\hline Argentina & $\begin{array}{l}\mathrm{CO}_{2}=f\left\{\text { Oil energy, } F D I, G D P, G D P^{2} \text { Green Energy, }\right. \\
\left.\text { Trade, } \mathrm{CO}_{2}(-1)\right\}(1,0,0,0,1,0,0)\end{array}$ & 17.4742 & Conclusive \\
\hline Brazil & $\begin{array}{l}\mathrm{CO}_{2}=f \text { \{Oil energy, FDI, GDP, GDP }{ }^{2} \text { Green Energy, } \\
\left.\text { Trade, } \mathrm{CO}_{2(-1)}\right\}(1,0,0,1,1,1,0)\end{array}$ & 16.33003 & Conclusive \\
\hline Iran & $\begin{array}{l}\mathrm{CO}_{2}=f\left\{\text { Oil energy, FDI, GDP, GDP }{ }^{2} \text { Green Energy, }\right. \\
\left.\text { Trade, } C \mathrm{CO}_{2}(-1)\right\}(1,0,0,0,0,0,0)\end{array}$ & 3.064 & Inconclusive \\
\hline Mexico & $\begin{array}{l}\mathrm{CO}_{2}=f\left\{\text { Oil energy, FDI, GDP, GDP }{ }^{2} \text { Green Energy, }\right. \\
\left.\text { Trade, } \mathrm{CO}_{2(-1)}\right\}(1,0,0,0,0,0,0)\end{array}$ & 11.38 & Conclusive \\
\hline South Africa & $\begin{array}{l}\mathrm{CO}_{2}=f\left\{\text { Oil energy, FDI, GDP, GDP }{ }^{2} \text { Green Energy, }\right. \\
\left.\text { Trade, } C \mathrm{CO}_{2}(-1)\right\}(1,0,1,1,1,0,0)\end{array}$ & 7.979 & Conclusive \\
\hline Canada & $\begin{array}{l}\mathrm{CO}_{2}=f\left\{\text { Oil energy, FDI, GDP, GDP }{ }^{2} \text { Green Energy, }\right. \\
\left.\text { Trade, } \mathrm{CO}_{2(-1)}\right\}(1,0,1,1,1,0,0)\end{array}$ & 3.0612 & Inconclusive \\
\hline Poland & $\begin{array}{l}\mathrm{CO}_{2}=f\left\{\text { Oil energy, FDI, GDP, GDP }{ }^{2} \text { Green Energy, }\right. \\
\left.\text { Trade, } C \mathrm{CO}_{2(-1)}\right\}(1,1,0,0,0,1,0)\end{array}$ & 23.004 & Conclusive \\
\hline Germany & $\begin{array}{l}\mathrm{CO}_{2}=f\left\{\text { Oil energy, FDI, GDP, GDP }{ }^{2} \text { Green Energy, }\right. \\
\left.\text { Trade, } C \mathrm{CO}_{2(-1)}\right\}(1,1,0,1,1,1,1)\end{array}$ & 3.789 & Conclusive \\
\hline
\end{tabular}

\subsection{Cointegration}

SIC criterion was used for choosing the optimal lag length for separate set of data of sample countries. The results indicated the appropriate lag length to be one. In cointegration bound testing, the comparison of $\mathrm{F}$ statistic against critical value is centred on lag imposition on differenced variable (Bahmani-Oskooee and Nasir, 2004).As long as the computed values fall between upper and lower limits, the model is inconclusive. If the computed values go below the lower limit, however, we do not reject the null hypothesis that there is no co-integration in this particular case. If the F-statistics that has been estimated is found to be higher than the critical value of the upper bound, the results considered as conclusive, indicating that the variables are cointegrated. As earlier specified, ECT gives useful information in confirming long-run relationships in this paradigm (Banerjee et al., 1998; Kremers et al., 1992). The Bounds test is found to be inconclusive for two nations Iran and Canada as the F statistic is found to lie within the critical values of lower and upper bounds. However, it is pertinent to mention that for Iran and Canada the error correction term was found negative and significant which establishes that the data series are cointegrated in the short run but long term cointegration is not conclusively established. For the other six countries long term cointegration relationship is conclusively established amongst the variables and F statistics is found to be exceeding the upper bound value signifying long-term relationship specified in table 4, (Kremers et al., 1992; Banerjee et al.,1998). 
Table 5: Stationarity Results of Panel Series

\begin{tabular}{|c|c|l|l|l|l|l|l|l|}
\hline \multicolumn{2}{|c|}{ Variables } & $\mathrm{CO}_{2}$ & $\begin{array}{l}\text { Oil } \\
\text { Energy }\end{array}$ & GDP & GDP $^{2}$ & Trade & $\begin{array}{l}\text { Green } \\
\text { energy }\end{array}$ & FDI \\
\hline \multirow{2}{*}{ Stationarity } & Level & -1.025 & -0.608 & -1.89 & 2.073 & $-2.97^{* *}$ & 2.1357 & $-3.93^{* *}$ \\
\cline { 2 - 9 } & First & $-3.133^{* *}$ & $-3.652^{* *}$ & $-5.983^{* *}$ & $-5.138^{* *}$ & ---- & $-6.769^{* *}$ & --- \\
\hline
\end{tabular}

465

466

467

Table 6:Panel Results -Random Effect Model

\begin{tabular}{|c|c|c|c|c|c|c|c|}
\hline Varia & & Coeffici & & & lue & Std. Error & $P$ value \\
\hline C & & -0.024 & & & 999 & 0.03137 & 0.4282 \\
\hline $\mathrm{D}(\mathrm{CO}$ & & -0.0648 & & & 995 & 0.0649 & 0.319 \\
\hline $\mathrm{D}(\mathrm{O}$ il E & rgy) & 0.0029 & & & 424 & 0.00039 & 0.0001 \\
\hline $\mathrm{D}(\mathrm{G}$ & & $7.63 \mathrm{E}-($ & & & 977 & $1.86 \mathrm{E}-07$ & 0.6825 \\
\hline $\mathrm{D}(\mathrm{GI}$ & & $-4.75 \mathrm{E}-$ & & & 765 & $1.23 \mathrm{E}-15$ & 0.6992 \\
\hline Tra & & $-8.74 \mathrm{E}-$ & & & 391 & -0.1391 & 0.8895 \\
\hline $\mathrm{D}$ (Green & ergy) & -0.085 & & & 574 & 0.04389 & 0.0519 \\
\hline $\mathrm{FL}$ & & $-9.40 \mathrm{E}-$ & & -0.0 & 4465 & $1.26 \mathrm{E}-12$ & 0.9407 \\
\hline & & Goo & Ines & $t$ and & Diagnosti & & \\
\hline R2 & $\begin{array}{l}\text { Adjusted } \\
\text { R2 }\end{array}$ & $\begin{array}{l}\text { Durbin } \\
\text { Watson }\end{array}$ & & $\begin{array}{l}\text { i } \\
\text { al } \\
\text { tion }\end{array}$ & $\underset{\text { Statistic }}{\text { F }}$ & $\begin{array}{c}\text { Hausman } \\
\text { Test (p } \\
\text { value) }\end{array}$ & $\begin{array}{c}\text { Cross-Section } \\
\text { dependence - } \\
\text { BP LM test } \\
\end{array}$ \\
\hline 0.350918 & 0.3241 & -0.4774 & & & 13.1297 & 1.8831 & 36.7461 \\
\hline & & & & & & $(.9660)^{++}$ & $(0.1246)^{+++}$ \\
\hline
\end{tabular}

468

469

470

471

472

473

474

475

476

477

478

479

480

481

482

483

484

485

486

487

${ }^{+}$Residuals are not cointegrated,${ }^{++}$Random Effect Model is more appropriate,

${ }^{++}$There is no cross-sectional dependence

\subsection{Panel Analysis}

Panel series were tested for presence of unit root as shown in Table 5. The panel series residuals were not found to be cointegrated as shown by the Panel ADF statistic -0.477454 , $\mathrm{p}=0.3165>.05$. RE as a percent of whole energy originally used in analysis was found to be I (2). Hence a proxy green energy series combustible and waste energy (\% of total energy) is used to run panel analysis to check the direction and magnitude of the coefficient of renewable energy as influencing the $\mathrm{CO}_{2}$ emissions and it is found negative and close to a significance level of 0.05 which is a very important finding of this study despite idiosyncrasy of the data series. It needs to be reemphasized that even the choice of data series that underestimates the use of renewable energy-use gives a clear finding of a negative relationship between carbon emissions and green energy with a compromised significance level of slightly above 0.05 cannot be ignored and is having a strong policy implication. Oil energy was found to be positively influencing carbon emissions as empirically tested in the previous research (Singhania and Saini, 2021; Shahbaz, and Tahir, 2013; Saboori and Sulaiman, 2013). The Kuznets curve hypothesis was not statistically significant (Table 6). However the trade and FDI were having a negative association with $\mathrm{CO}_{2}$, but insignificant. In 
the country-wise analysis as well the Kuznets curve hypothesis was very weak for countries like Mexico with coefficient value of 6.21E-10 and -4.42E-24 found significant for Mexico and Poland respectively. Coefficient of the regressors, trade and FDI were having a negative association with $\mathrm{CO}_{2}$, however they were not found to be significant. (Table 6). Our results seem to be in alignment with a recent paper by Nicole (2019) wherein the validity of the Environmental Kuznets Curve has been examined and questioned. However, studies by $\mathrm{He}$ and Richard, 2010; Rashid, 2009; Liang, 2008 validate the EKC hypothesis.

Breusch Pagan Test for cross-sectional dependence is relevant since $\mathrm{t}>\mathrm{n}$ and it found that cross sectional dependence is not present $(36.7461, \mathrm{p}=0.1246>.05)$. The direction of association of the regressors are aligned to previous research. The robustness of the model can be improved by increasing the number of countries in the panel. As shown in figure 1 the prediction of $\mathrm{CO}_{2}$ emissions is not as robust for developed countries as it is found for the developing countries.

\subsection{Analysis of Granger Causality}

Table 7: Granger Causality Pairwise ${ }^{7}$

\begin{tabular}{|r|r|r|r|r|r|r|r|}
\hline Panel series & $\mathrm{CO}_{2}$ Emissions & $\begin{array}{r}\text { Oil } \\
\text { Energy }\end{array}$ & GDP & GDP $^{2}$ & Trade & $\begin{array}{r}\text { Green } \\
\text { Energy }\end{array}$ & FDI \\
\hline $\mathrm{CO}_{2}$ & 1 & 1.7122 & .01893 & .00552 & 1.0733 & 0.85179 & 0.56339 \\
\hline Oil Energy & 1.90406 & 1 & 1.29207 & 1.15088 & 0.51971 & 1.59655 & 0.2432 \\
\hline GDP & $4.04978^{* *}$ & $14.2014 * *$ & 1 & $8.35154 * *$ & 0.84916 & $4.46880^{* *}$ & 0.18077 \\
\hline GDP & $3.7166^{* *}$ & $12.8180^{* *}$ & $8.5269^{* *}$ & 1 & 0.02307 & $5.01989^{* *}$ & 0.18077 \\
\hline Trade & 0.98376 & 0.92728 & .00896 & .085962 & 1 & 0.95984 & 0.18077 \\
\hline $\begin{array}{r}\text { Green } \\
\text { Energy }\end{array}$ & $2.8771^{*}$ & $91.111^{* *}$ & .02300 & 0.03777 & 0.29527 & 1 & $5.57422^{* *}$ \\
\hline FDI & 0.5639 & 0.4965 & 0.01470 & 0.03735 & 0.03195 & 0.03195 & 1 \\
\hline
\end{tabular}

$* *$ Significant at $0.05 *$ significant at 0.10

Table 7 exhibits pairwise panel causality test results for the Random Effect estimation done for the panel data. One way causation runs from GDP to $\mathrm{CO}_{2}$ emission and confirmed statistical significance. The outcomes of Shafik (1992) and Holtz-Eakin and Selden (1995) indicate that pollutant emissions increase monotonically with income levels A univariate Granger Causality running from $\mathrm{GDP}^{2}$ to $\mathrm{CO}_{2}$ emissions. Apergis and Tang, 2013; Baranzini et al., 2013; Tang and Tan, 2013; Ozturk, 2010; Payne, 2010; Wolde-Rufael, 2005, 2009; Kraft and Kraft, 1978; considering a causal association among energy use and GDP growth and there is enough signal provided by studies using various econometric methods. Study of Zhang and Cheng (2009) also support results of Granger Causality presented here. Univariate causation was also found significant running from GDP to NRE. Obviously, that confirmed the one-way causality to exist between squared GDP and oil energy. Univariate causality running from GDP and GDP ${ }^{2}$ to Green energy was also significant. GDP growth will boost renewable energy use is aligned with the results of earlier studies. However, Apergis and Payne (2010); Paul and Bhattacharya (2004); Asafu-Adjaye (2000); found univariate causation running from RE to GDP. Environment conservation always is the focus of nations after achieving the minimum threshold of development. The one-way causality running from green energy to $\mathrm{CO}_{2}$ was found significant at $10 \%$ level which is a significant indicator given the fact that an underestimated renewable energy series was used to assess Granger Causality

\footnotetext{
${ }^{7}$ Pair wise Granger Causality conducted at country level has not been attached to keep the analysis less dense. It may be made available if it interests the reader.
} 
as the RE-use as a \% of total energy was found I (2) for the panel constituting eight countries. As depicted in the figure 1, fitted model is better for the developing countries vis a vis the developed countries.

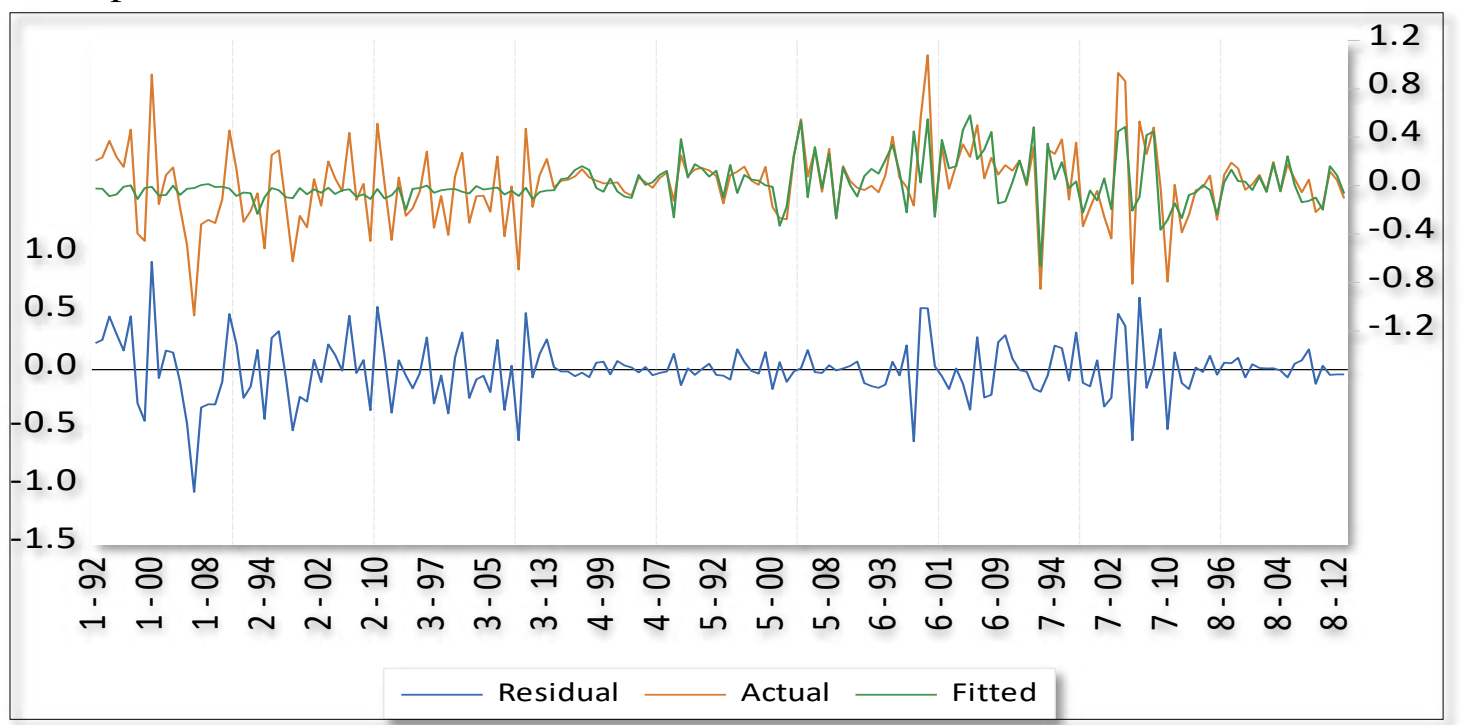

Figure 1: Plot of Residual, Actual and Fitted carbon emissions

\section{Conclusion and Policy Implications}

The current paper covers five developing countries and three developed countries analysis comprising of Argentina Brazil, Iran, South Africa, Mexico and Germany, Poland, Canada. Granger Causation conducted for panel data also confirm the nexus between green energy use and $\mathrm{CO}_{2}$ emissions, despite using an underestimated series reflecting green energy usage for panel data analysis aligned with previous research and environmental theory.

The results exhibit that the use of non-renewable energy does not have desirable effect on the environment which leads to gradual degradation, consistent with Kashif Abbasi, et al 2020, Razmo A. et al. 2021, while green energy lessens the environmental degradation that may prove helpful to reduce environmental hazards is validated by the long run and short run estimates of ARDL model (Table 2 and 3). The directional influence of green energy on $\mathrm{CO}_{2}$ is found negative for all countries except Mexico. It is found significant for Argentina, Brazil, Iran in the category of developing countries for current period and significant for South Africa, Poland and Germany for one period lag. However, for Canada the relationship is negative but not significant between green energy and carbon emissions. These results are indicative of the fact that green energy usage is positively linked to lessening the environmental degradation across six countries and the strength of association is noteworthy in the long run model (Table 2). Univariate causality running from green energy to $\mathrm{CO}_{2}$ was found significant at 0.06 level which is a significant indicator given the fact that an underestimated renewable energy series was used to assess Granger Causality. The original indicator of renewable energyuse expressed in terms of a percentage of total energy was found to be I (2) for the panel constituting eight countries, hence it had to be dropped. Onesided Granger Causality was also found significant running from GDP to non-renewable oil energy. One way causation moving from GDP and $\mathrm{GDP}^{2}$ to Green energy was also significant.All these results reverberating all through in the analysis are supported by UN Environment Assembly Sustainable Development Goals. (2019). 
562 There were lot of data idiosyncrasies that were handled while attempting data analysis 563 especially regarding country-wise data series found to be I (2), which added to limitations in our study.Firstly, the renewable energy (\% of total energy) was found to be integrated at level two (I(2)) for Iran and South Africa, which encouraged the author to use an alternative variable for the analysis i.e. combustible renewables and waste (\% of total energy). However, at country level across five developing and three developed countries the short run and long run association was found to be largely stable. It is pertinent to mention here that the panel series representing green energy (renewable energy as \% of total energy) was found to be I (2) hence for running panel analysis on eight countries the second-best alternative was choseni.e., Combustible renewables and waste (\% of total energy). This series is not as best an alternative representing renewable energy usage, yet the direction of results is quite robust in indicating that nations should switch to use of renewable energy alternatives best suited for them given the geographical location, topography, and natural resource availability.Secondly,we have considered $\mathrm{CO}_{2}$ emissions only as an environmental degradation indicator in this current study and other GHGs are outside the scope of this paper. Thirdly, selection of countries was narrowed due to data features.

The study very convincingly validates the fact that switching to renewable energy resources are in the interests of the nations to achieve sustainable growth. More needs to be done in the form of increased environmental awareness, global and nationwide concerted collaboration for environmental protection (Shahbaz, Nasreen, Abbas, and Anis, 2015; Go lgeci, Gligor, Tatoglu, and Arda, 2019). Increased intervention by governments in channelling and sequencing foreign direct investments in the social and green technology sectors, tapping cleaner alternative technology, promoting awareness amongst the public about the issues related with energy use may go a long way in moving towards sustainable way of production, consumption and investment activities. It should be made mandatory for multinational companies to embrace strict disclosure norms on social and environmental dimensions. By adopting green supply management through Public-Private partnership, we may go a long way in effectively reaping the benefits of globalized investments (Ansari, Khan, and Ganaie, 2019). Collaboration for environmental protection is an essential facet and the very basis of civil, economic progress steering environmental sustainability. The spread of public awareness about polluting industries that are piling hazardous waste is essential for sustainable development. Companies, people, countries should be induced and incentivised to embrace cleaner technology using biofuel, solar energy, and wind energy, in their production and consumption processes. There is a need for new investments to come up for creation, promotion and use of enabling technologies to usher in and maximize the renewable energy resource use in day to day lives. This would reduce both the carbon and the material footprint ensuring better health of the citizens, greater sustainable growth for all the stakeholders. Finally, there is an urgent need for policymakers to consolidate their management and supervisory obligations towards the execution and implementation of investments that have low carbon intensity (Singhania and Saini, 2021). In addition, development that leaves less material footprint should be the focus of the producers, investors, and consumers. There is an increased need for nations and people to realize that both carbon and material footprint are cause of concern and needs to be reduced. However, even the most talked about electrical vehicles will cause huge material footprint ${ }^{8}$. Grow now and fix it later propositionof EKC is having a very weak credibility as per the findings of this research.

\footnotetext{
8 To satisfy material needs and support economic growth huge pressure is placed on the environment. The global material footprint increased from 43 billion metric tons in 1990 to around 54 billion in 2000, and further increased to 92 billion in 2017.
} 
608 -Ethical Approval: There are three authors and all have work as per author contribution, and 609 ethical approval has been given to contribute to this journal.

610 -Consent to Participate: All author has given their consent to participate in this research

611 area where we have used secondary data sources.

612 -Consent to Publish: All author has given their consent to publish in this research area

613 -Authors Contributions:Pratibha Rai has frozen the methodology, analysed, and interpreted the results and is a major contributor in writing the manuscript in consultation with Neha

615 Saini . Priya Gupta conceptualised the theoretical framework. Neha Saini then finally

616 reviewed the manuscripts and gave her valuable input in framing the conclusion and policy

617 implications. All authors read and approved the final manuscript.

618 -Funding: NA

619 -Competing Interests: No competing interest among the authors

620 -Availability of data and materials: Secondary data sources from WDI has been used and

621 specified in manuscript

622

623

624

625

626

627

628

629

630

631

632

633

634

635

636

637

638

639

640

\section{References}

- Abbasi, K., Jiao, Z., Shahbaz, M., \& Khan, A. (2020). Asymmetric impact of renewable and nonrenewable energy on economic growth in Pakistan: New evidence from a nonlinear analysis. Energy Exploration \& Exploitation, 38(5), 1946-1967 https://doi.org/10.1177/0144598720946496

- Alvarez-Herranz, A., Balsalobre, D., Cantos, J. M., \& Shahbaz, M. (2017). Energy innovations-GHG emissions nexus: Fresh empirical evidence from OECD countries. Energy Policy, 101, 90-100 https://doi.org/10.1016/j.enpol.2016.11.030

- Ansari, M. A., Khan, N. A., \&Ganaie, A. A. (2019). Does foreign direct investment impede environmental quality in Asian countries? A panel data analysis. OPEC Energy Review., 43(2), 109135 https://doi.org/10.1111/opec.12144

- Apergis, N., \& Payne, J. E. (2010). Renewable energy consumption and economic growth: evidence from a panel of OECD countries. Energy policy, 38(1), 656-660. https://doi.org/10.1016/j.enpol.2009.09.002.

- $\quad$ Apergis, N., \& Tang, C. F. (2013). Is the energy-led growth hypothesis valid? New evidence from a sample of 85 countries. Energy Economics, 38, 24-31 https://doi.org/10.1016/j.eneco.2013.02.007 
- Apergis, N., Chang, T., Gupta, R., \&Ziramba, E. (2016). Hydroelectricity consumption and economic growth nexus: Evidence from a panel of ten largest hydroelectricity consumers. Renewable and Sustainable Energy Reviews, 62, 318-325https://doi.org/10.1016/j.rser.2016.04.075

- Apergis, N., Jebli, M. B., \& Youssef, S. B. (2018). Does renewable energy consumption and health expenditures decrease carbon dioxide emissions? Evidence for sub-Saharan Africa countries. Renewable energy, 127, 1011-1016 https://doi.org/10.1016/j.renene.2018.05.043

- Asafu-Adjaye, J. (2000). The relationship between energy consumption, energy prices and economic growth: time series evidence from Asian developing countries. Energy economics, 22(6), 615625.https://doi.org/10.1016/S0140-9883(00)00050-5

- Bahmani-Oskooee, M., \& Nasir, A. B. M. (2004). ARDL approach to test the productivity bias hypothesis. Review of development Economics, 8(3), 483-488 https://doi.org/10.1111/j.14679361.2004.00247.x

- Banerjee, A., Dolado, J., \& Mestre, R. (1998). Error-correction mechanism tests for cointegration in a single-equation framework. Journal of time series analysis, 19(3), 267-283

https://doi.org/10.1111/1467-9892.00091

- Baranzini, A., Weber, S., Bareit, M., \&Mathys, N. A. (2013). The causal relationship between energy use and economic growth in Switzerland. Energy Economics, 36, 464470.https://doi.org/10.1016/j.eneco.2012.09.015

- Birdsall, N., \& Wheeler, D. (1993). Trade policy and industrial pollution in Latin America: where are the pollution havens?. The Journal of Environment \& Development, 2(1), 137149.https://doi.org/10.1177/107049659300200107

- Blonigen, B. A. (2005). A review of the empirical literature on FDI determinants. Atlantic economic journal, 33(4), 383-403. https://doi.org/10.1007/s11293-005-2868-9

- Bollen, K. A., \& Brand, J. E. (2010). A general panel model with random and fixed effects: A structural equations approach. Social Forces, 89(1), 1-34. https://doi.org/10.1353/sof.2010.0072

- Boutabba, M. A. (2014). The impact of financial development, income, energy and trade on carbon emissions: evidence from the Indian economy. Economic Modelling, 40, 3341.https://doi.org/10.1016/j.econmod.2014.03.005

- Buckley, P. J., \& Casson, M. C. (1998). Analyzing foreign market entry strategies: Extending the internalization approach. Journal of international business studies, 29(3), 539-561. https://doi.org/10.1057/palgrave.jibs.8490006

- Caruso, G., Colantonio, E., \&Gattone, S. A. (2020). Relationships between renewable energy consumption, social factors, and health: a panel vector auto regression analysis of a cluster of $12 \mathrm{EU}$ countries. Sustainability, 12(7), 2915. https://doi.org/10.3390/su12072915

- Cernic, J. L. (2012). The 2011 Update of the OECD Guidelines for Multinational Enterprises. ASIL Insight, 16(4).https://asil.org/insights/volume/16/issue/4/2011-update-oecd-guidelines-multinationalenterprises

- Chan, C. M., Makino, S., \&Isobe, T. (2006). Interdependent behavior in foreign direct investment: The multi-level effects of prior entry and prior exit on foreign market entry. Journal of International Business Studies, 37(5), 642-665. https://doi.org/10.1057/palgrave.jibs.8400216

- Charfeddine, L., \&Kahia, M. (2019). Impact of renewable energy consumption and financial development on $\mathrm{CO} 2$ emissions and economic growth in the MENA region: a panel vector autoregressive (PVAR) analysis. Renewable energy, 139, 198213.https://doi.org/10.1016/j.renene.2019.01.010

- Chichilnisky, G. (1994). North-south trade and the global environment. The American Economic Review, 851-874.http://www.jstor.org/stable/2118034

- Claessens, S., \&Feijen, E. (2007). Financial sector development and the millennium development goals (No. 89). World Bank Publications.https://dx.doi.org/10.2139/ssrn.950269

- Cole, M. A., Elliott, R. J., \& Strobl, E. (2008). The environmental performance of firms: The role of foreign ownership, training, and experience. Ecological Economics, 65(3), 538546.https://doi.org/10.1016/j.ecolecon.2007.07.025

- Copeland, B. R., \& Taylor, M. S. (1994). North-South trade and the environment. The quarterly journal of Economics, 109(3), 755-787. https://doi.org/10.2307/2118421 
- Copeland, B. R., \& Taylor, M. S. (2004). Trade, growth, and the environment. Journal of Economic literature, 42(1), 7-71. http://www.jstor.org/stable/3217036

- Dasgupta, S., Hong, J. H., Laplante, B., \&Mamingi, N. (2006). Disclosure of environmental violations and stock market in the Republic of Korea. Ecological economics, 58(4), 759777.https://doi.org/10.1016/j.ecolecon.2005.09.003

- Dasgupta, S., Laplante, B., \&Mamingi, N. (2001). Pollution and capital markets in developing countries. Journal of Environmental Economics and management, 42(3), 310335.https://doi.org/10.1006/jeem.2000.1161

- Dasgupta, S., Laplante, B., Wang, H., \& Wheeler, D. (2002). Confronting the environmental Kuznets curve. Journal of economic perspectives, 16(1), 147-168. https://doi.org/10.1257/0895330027157

- Dinda, S. (2004). Environmental Kuznets curve hypothesis: a survey. Ecological economics, 49(4), 431-455.https://doi.org/10.1016/j.ecolecon.2004.02.011

- Engle, R. F., \& Granger, C. W. (1987). Co-integration and error correction: representation, estimation, and testing. Econometrica: journal of the Econometric Society, 251-276.https://doi.org/10.2307/1913236

- Eskeland, G. S., \& Harrison, A. E. (2003). Moving to greener pastures? Multinationals and the pollution haven hypothesis. Journal of development economics, 70(1), 1-23. http://dx.doi.org/10.1016/S0304-3878(02)00084-6

- Feridun, Mete, Olusi, Janet O. And Folorunso, Benjamin, (2006), Analyzing the Impact of Globalization on Economic Development in Developing Economies: An Application of Error Correction Modelling (Ecm) to Nigeria, Applied Econometrics and International Development, 6(3), https://ssrn.com/abstract $=1247850$

- Fetscherin, M., Voss, H., \&Gugler, P. (2010). 30 Years of foreign direct investment to China: An interdisciplinary literature review. International business review, 19(3), 235246.https://doi.org/10.1016/j.ibusrev.2009.12.002

- Ghosh, S. (2010). Examining carbon emissions economic growth nexus for India: a multivariate cointegration approach. Energy policy, 38(6), 3008-3014.https://doi.org/10.1016/j.enpol.2010.01.040

- Gölgeci, I., Gligor, D. M., Tatoglu, E., \& Arda, O. A. (2019). A relational view of environmental performance: What role do environmental collaboration and cross-functional alignment play? Journal of Business Research, 96, 35-46.https://doi.org/10.1016/j.jbusres.2018.10.058

- Gradus, R., \& Smulders, S. (1993). The trade-off between environmental care and long- term growthpollution in three prototype growth models. Journal of Economics, 58 (1), 2551.https://www.jstor.org/stable/41794297

- Gray, K. R. (2002). Foreign direct investment and environmental impacts-is the debate over? Review of European Community \& International Environmental Law, 11(3), 306313.https://doi.org/10.1111/1467-9388.00329

- Grossman, G. M., \& Krueger, A. B. (1991). Environmental impacts of a North American free trade agreement. https://doi.org/10.3386/w3914

- Grossman, G. M., \& Krueger, A. B. (1995). Economic growth and the environment. The quarterly journal of economics, 110(2), 353-377.https://doi.org/10.3386/w4634

- He, J., \& Richard, P. (2010). Environmental Kuznets curve for CO2 in Canada. Ecological economics, 69(5), 1083-1093.https://doi.org/10.1016/j.ecolecon.2009.11.030

- Hoffmann, R., Lee, C. G., Ramasamy, B., \& Yeung, M. (2005). FDI and Pollution: A Granger Causality Test using Panel Data. Journal Of International Development: The Journal of the Development Studies Association, 17(3), 311-317.http://dx.doi.org/10.1002/jid.1196

- Holtz-Eakin, D., \& Selden, T. M. (1995). Stoking the fires? CO2 emissions and economic growth. Journal of public economics, 57(1), 85-101. https://doi.org/10.1016/0047-2727(94)01449-X

- Jayanthakumaran, K., Verma, R., \& Liu, Y. (2012). CO2 emissions, energy consumption, trade and income: a comparative analysis of China and India. Energy Policy, 42, 450460.https://doi.org/10.1016/j.enpol.2011.12.010

- Jensen, V. (1996). The pollution haven hypothesis and the industrial flight hypothesis: some perspectives on theory and empirics. Centre for Development and the Environment (Working Paper 
1996.5), University of Oslo, Oslo.https://www.informea.org/en/literature/trade-and-environmentpollution-haven-hypothesis-and-industrial-flight-hypothesis-some

- Johansen, S., \&Juselius, K. (1990). Maximum likelihood estimation and inference on cointegrationwith appucations to the demand for money. Oxford Bulletin of Economics and statistics, 52(2), 169210.https://doi.org/10.1111/j.1468-0084.1990.mp52002003.x

- Jorgenson, A. K. (2007). Does foreign investment harm the air we breathe and the water we drink? A cross-national study of carbon dioxide emissions and organic water pollution in less-developed countries, 1975 to 2000. Organization \& Environment, 20(2), 137156.https://doi.org/10.1177\%2F1086026607302153

- Karsch, N. M. (2019). Examining the validity of the environmental Kuznets curve. Consilience, (21), 32-50.https://doi.org/10.7916/consilience.v0i21.5727

- Keller, W., \& Levinson, A. (2002). Pollution abatement costs and foreign direct investment inflows to US states. Review of Economics and Statistics, 84(4), 691703.http://dx.doi.org/10.1162/003465302760556503

- Koengkan, M., \&Fuinhas, J. A. (2017). The Negative Impact of Renewable Energy Consumption on Carbon Dioxide Emissions: An Empirical Evidence from South American Countries. RevistaBrasileira de EnergiasRenováveis, 6(5), 893-914.http://dx.doi.org/10.5380/rber.v6i5.49252

- Kraft, J., \& Kraft, A. (1978). On the relationship between energy and GNP. The Journal of Energy and Development, 401-403.https://www.jstor.org/stable/24806805

- Kremers, J. J., Ericsson, N. R., \&Dolado, J. J. (1992). The power of cointegration tests. Oxford bulletin of economics and statistics, 54(3), 325-348.

\section{https://doi.org/10.1111/j.1468-0084.1992.tb00005.x}

- Liang, F. H. (2008). Does foreign direct investment harm the host country's environment? Evidence from China. Evidence from China (Nov 28, 2008).https://dx.doi.org/10.2139/ssrn.1479864

- Liang, Q., \& Jian-Zhou, T. (2006). Financial development and economic growth: Evidence from China. China economic review, 17(4), 395-411.https://doi.org/10.1016/j.chieco.2005.09.003

- Majid, M. A. (2020). Renewable energy for sustainable development in India: current status, future prospects, challenges, employment, and investment opportunities. Energy, Sustainability and Society, 10(1), 1-36. https://doi.org/10.1186/s13705-019-0232-1

- Menegaki, A. N. (2019). The ARDL method in the energy-growth nexus field; best implementation strategies. Economies, 7(4), 105.https://doi.org/10.3390/economies7040105

- Mert M, Bölük G. (2016), Do foreign direct investment and renewable energy consumption affect the $\mathrm{CO} 2$ emissions? New evidence from a panel ARDL approach to Kyoto Annex countries. Environ Sci Pollut Res Int. 2016 Nov;23(21):21669-21681. Epub 2016 Aug 13. PMID: 27522202. https://doi.org/10.1007/s11356-016-7413-7

- Mert, M., \&Caglar, A. E. (2020). Testing pollution haven and pollution halo hypotheses for Turkey: a new perspective. Environmental Science and Pollution Research,27(26), 32933-32943.) DOI: $10.1007 / \mathrm{s} 11356-020-09469-7$

- Meyer, K. E. (2004). Perspectives on multinational enterprises in emerging economies. Journal of International Business Studies, 35(4), 259-276.https://doi.org/10.1057/palgrave.jibs.8400084

- Narayan, P. K. (2005). The saving and investment nexus for China: evidence from cointegration tests. Applied economics, 37(17), 1979-1990. https://doi.org/10.1080/00036840500278103.

- Narayan, P. K., \& Narayan, S. (2010). Carbon dioxide emissions and economic growth: Panel data evidence from developing countries. Energy policy, 38(1), 661666.https://doi.org/10.1016/j.enpol.2009.09.005

- Narayan, P. K., \& Popp, S. (2010). A new unit root test with two structural breaks in level and slope at $\begin{array}{lllll}\text { unknown time. Journal of } & \text { Applied } & \text { Statistics, 37(9), } & \text { 1425-1438. }\end{array}$ https://doi.org/10.1080/02664760903039883.

- Narayan, P. K., Narayan, S., \& Popp, S. (2010). Does electricity consumption panel Granger cause GDP? A new global evidence. Applied Energy, 87(10), 32943298.https://doi.org/10.1016/j.apenergy.2010.03.021 
- Narayan, P. K., Narayan, S., \& Prasad, A. (2008). A structural VAR analysis of electricity consumption and real GDP: Evidence from the G7 countries. Energy Policy, 36(7), 27652769.https://doi.org/10.1016/j.enpol.2008.02.027

- Narayan, P. K., Saboori, B., \&Soleymani, A. (2016). Economic growth and carbon emissions. Economic Modelling, 53, 388-397.https://doi.org/10.1016/j.econmod.2015.10.027

- Nguyen, K. H., \&Kakinaka, M. (2019). Renewable energy consumption, carbon emissions, and development stages: Some evidence from panel cointegration analysis. Renewable Energy, 132, 10491057.https://doi.org/10.1016/j.renene.2018.08.069

- Ozturk, I. (2010). A literature survey on energy-growth nexus. Energy policy, 38(1), 340349.https://doi.org/10.1016/j.enpol.2009.09.024

- Özdemir, Özlem., \&Özokcu, Selin. (2017). Ecoomic growth, energy, and environmental Kuznets curve. Renewable and Sustainable Energy Reviews. 72, 639-647. https://doi.org/10.1016/j.rser.2017.01.059

- Palz, W. (1994). Role of new and renewable energies in future energy systems. International journal of solar energy, 14(3), 127-140.https://doi.org/10.1080/01425919408909805

- Panayotou, T. (1997). Demystifying the environmental Kuznets curve: turning a black box into a policy tool. Environment and development economics, 2(4), 465484.https://doi.org/10.1017/S1355770X97000259

- Pao, H. T., \& Tsai, C. M. (2011). Multivariate Granger causality between CO2 emissions, energy consumption, FDI (foreign direct investment) and GDP (gross domestic product): evidence from a panel of BRIC (Brazil, Russian Federation, India, and China) countries. Energy, 36(1), 685693.https://doi.org/10.1016/j.energy.2010.09.041

- Paul, J., \& Benito, G. R. (2018). A review of research on outward foreign direct investment from emerging countries, including China: what do we know, how do we know and where should we be heading?. Asia Pacific Business $\quad$ Review, 24(1), 90-115. https://doi.org/10.1080/13602381.2017.1357316

- Paul, S., \& Bhattacharya, R. N. (2004). Causality between energy consumption and economic growth in India: a note on conflicting results. Energy economics, 26(6), 977983.https://doi.org/10.1016/j.eneco.2004.07.002

- Payne, J.E. (2010), "Survey of the international evidence on the causal relationship between energy consumption and growth", Journal of Economic Studies, 37(1) 53-95. https://doi.org/10.1108/01443581011012261

- Perkins, R., \&Neumayer, E. (2008). Fostering environment efficiency through transnational linkages? Trajectories of $\mathrm{CO} 2$ and SO2, 1980-2000. Environment and Planning A, 40(12), 29702989.https://doi.org/10.1068\%2Fa4089

- Perkins, R., \&Neumayer, E. (2008). Fostering environment efficiency through transnational linkages? Trajectories of $\mathrm{CO} 2$ and SO2, 1980-2000. Environment and Planning A, 40(12), 29702989.https://doi.org/10.1068\%2Fa4089

- Perkins, R., \&Neumayer, E. (2009). Transnational linkages and the spillover of environment-efficiency into developing countries. Global Environmental Change, 19(3), 375383.https://doi.org/10.1016/j.gloenvcha.2009.05.003

- Persson, T. A., Azar, C., \& Lindgren, K. (2006). Allocation of CO2 emission permits-economic incentives for emission reductions in developing countries. Energy Policy, 34(14), 18891899.https://doi.org/10.1016/j.enpol.2005.02.001

- Pesaran, M., and Pesaran, B. (1997). Working with Microfit 4.0: Interactive Econometric Analysis. Oxford: $\quad$ Oxford University Press. https://www.scirp.org/reference/ReferencesPapers.aspx?ReferenceID=829654

- Pesaran, M., Shin, Y., and Smith, R. J. (2001). Bounds Testing Approaches to the Analysis of Level Relationships. Journal of Applied Econometrics, 16, 289-326.https://doi.org/10.1002/jae.616

- Pesaran, M.H. and Shin, Y. (1999) An Autoregressive Distributed Lag Modelling Approach to Cointegration Analysis. In: Strom, S., Ed., Chapter 11 in Econometrics and Economic Theory in the 20th Century the Ragnar Frisch Centennial Symposium, Cambridge University Press, Cambridge, 371413.https://doi.org/10.1017/CCOL521633230.011 
- Prieur, Fabien. (2009). The environmental Kuznets curve in a world of irreversibility. Economic Theory, 40(1), 57-90.https://doi.org/10.1007/s00199-008-0351-y

- Rashid, S. (2009). The environmental Kuznets curve case for the USA and the BRIC countries (Doctoral dissertation, Georgia Institute of Technology).https://core.ac.uk/display/4733864

- Razmjoo, A., Kaigutha, L. G., Rad, M. V., Marzband, M., Davarpanah, A., \&Denai, M. (2020). A Technical analysis investigating energy sustainability utilizing reliable renewable energy sources to reduce $\mathrm{CO} 2$ emissions in a high potential area. Renewable Energy. 164 (C), 4657https://doi.org/10.1016/j.renene.2020.09.042

- Robeco SAM, publishes The Sustainability Yearbook 2019, under "SAM" branding accessed from https://www.robecosam.com/en/media/press-releases/2019/robecosam-publishes-the-sustainabilityyearbook-2019-under-sam-branding.ht $\mathrm{ml}$.

- Saboori, B., \&Sulaiman, J. (2013). CO2 emissions, energy consumption and economic growth in Association of Southeast Asian Nations (ASEAN) countries: A cointegration approach. Energy, 55, 813-822.https://doi.org/10.1016/j.energy.2013.04.038

- Saini, N., and Sighania, M., (2019). Environmental impact of economic growth, emission and FDI: systematic review of reviews, Qualitative Research in Financial Markets, 11(1), 81-134. https://doi.org/10.1108/QRFM-09-2017-0087

- Sen, S., Khazanov, G., \&Kishimoto, Y. (2011). Environment, renewable energy and reduced carbon emissions. Radiation Effects and Defects in Solids, 166(10), 834842.http://dx.doi.org/10.1080/10420150.2011.617752

- Shafik, N., \& Bandyopadhyay, S. (1992). Economic growth and environmental quality: time-series and cross-country evidence (Vol. 904). World Bank Publications.http://documents.worldbank.org/curated/en/833431468739515725/Economic-growth-andenvironmental-quality-time-series-and-cross-country-evidence

- Shahbaz, M., \& Lean, H. H. (2012). Does financial development increase energy consumption? The role of industrialization and urbanization in Tunisia. Energy policy, 40, 473479.https://doi.org/10.1016/j.enpol.2011.10.050

- Shahbaz, M., Khan, S., \& Tahir, M. I. (2013). The dynamic links between energy consumption, economic growth, financial development and trade in China: fresh evidence from multivariate framework analysis. Energy economics, 40, 8-21.https://doi.org/10.1016/j.eneco.2013.06.006

- Shahbaz, M., Nasreen, S., Abbas, F., \& Anis, O. (2015). Does foreign direct investment impede environmental quality in high-, middle-, and low-income countries?. Energy Economics, 51, 275287.https://doi.org/10.1016/j.eneco.2015.06.014

- Shahbaz, M., Shahzad, S. J. H., Mahalik, M. K., \&Hammoudeh, S. (2018). Does globalisation worsen environmental quality in developed economies?. Environmental Modeling \& Assessment, 23(2), 141156.https://doi.org/10.1007/s10666-017-9574-2

- Shao, Y. (2018). Does FDI affect carbon intensity? New evidence from dynamic panel analysis. International Journal of Climate Change Strategies and Management.https://doi.org/10.1108/IJCCSM-03-2017-0062

- Sharif, A., Raza, S.A. Ozturk, I. (2007) Assessment Report of the Intergovernmental Panel on Climate Change, IPCC, Geneva, 151, ISBN: 978-92-9169-143-2.

- Singhania, M., \& Saini, N. (2021). Demystifying pollution haven hypothesis: Role of FDI. Journal of Business Research, 123, 516-528.https://doi.org/10.1016/j.jbusres.2020.10.007

- Stern, D. I. (2003). The environmental Kuznets curve, Online Encyclopedia of Ecological Economics. http://www.ecoeco.org/pdf/stern.pdf).\&\#32

- Stern, D. I. (2004). The rise and fall of the environmental Kuznets curve. World development, 32(8), 1419-1439.https://doi.org/10.1016/j.worlddev.2004.03.004

- Stern, D. I., \& Common, M. S. (2001). Is there an environmental Kuznets curve for sulfur? Journal of Environmental Economics and Environmental Management, 41, 162178.https://doi.org/10.1006/jeem.2000.1132 
- Stern, D. I., Common, M. S., \&Barbier, E. B. (1996). Economic growth and environmental degradation: The environmental Kuznets curve and sustainable development. World Development, 24, 1151-1160.https://doi.org/10.1016/0305-750X(96)00032-0

- Stern, N., \& Stern, N. H. (2007). The economics of climate change: the Stern review. cambridge University press.https://doi.org/10.1017/CBO9780511817434

- Stokey, N. L. (1998). Are there limits to growth? International economic review, 39(1), .31-1 https://doi.org/10.2307/2527228

- Soytas, U., \& Sari, R. (2009). Energy consumption, economic growth, and carbon emissions: challenges faced by an EU candidate member. Ecological economics, 68(6), 16671675.https://doi.org/10.1016/j.ecolecon.2007.06.014

- Sun, C., Zhang, F., \& Xu, M. (2017). Investigation of pollution haven hypothesis for China: an ARDL approach with breakpoint unit root tests. Journal of cleaner production, 161, 153164.https://doi.org/10.1016/j.jclepro.2017.05.119

- Tadesse, S. A. (2005). Financial development and technology. Available at SSRN 681562.https://dx.doi.org/10.2139/ssrn.681562

- Talukdar, D., \& Meisner, C. M. (2001). Does the private sector help or hurt the environment? Evidence from carbon dioxide pollution in developing countries. World development, 29(5), 827840.https://doi.org/10.1016/S0305-750X(01)00008-0

- Tamazian, A., \& Rao, B. B. (2010). Do economic, financial and institutional developments matter for environmental degradation? Evidence from transitional economies. Energy economics, 32(1), 137145.https://doi.org/10.1016/j.eneco.2009.04.004

- Tang, C. F., \& Tan, E. C. (2013). Exploring the nexus of electricity consumption, economic growth, energy prices and technology innovation in Malaysia. Applied Energy, 104, 297305.https://doi.org/10.1016/j.apenergy.2012.10.061

- UNEP, U. Environment Assembly and Governing Council. Webpage: http://web. unep. org/environmentassembly/un-environment-assembly-and-governing-council [Retrieved July 8, 2019].https://www.unep.org/environmentassembly/

- Van den Bergh, J. C., \& Nijkamp, P. (1994). Dynamic macro modelling and materials balance: Economic-environmental integration for sustainable development. Economic Modelling, 11(3), 283307. https://doi.org/10.1016/0264-9993(94)90006-X

- Waslekar, Sundeep Saahil. (2013). World environmental Kuznets curve and the global future. Procedia Social and Behavioral Sciences, 133, 310-319. https://doi.org/10.1016/j.sbspro.2014.04.197

- Wheeler, D. (2001). Racing to the bottom? Foreign investment and air pollution in developing countries. The Journal of Environment \& Development, 10(3), 225-245. https://doi.org/10.1177\%2F10704965-0101003-02

- Wolde-Rufael, Y. (2005). Energy demand and economic growth: the African experience. Journal of Policy Modeling, 27(8), 891-903.https://doi.org/10.1016/j.jpolmod.2005.06.003

- Wolde-Rufael, Y. (2009). Energy consumption and economic growth: the experience of African countries revisited. Energy Economics, 31(2), 217-224.https://doi.org/10.1016/j.eneco.2008.11.005

- World Bank (2000), Is Globalization Causing a "Race to the Bottom" Environmental Standard? PREM Economic Policy Group and Development Economics Group, April 2000, http://web.archive.org/web/20000816160722/http://www.worldbank.org//

- Zarsky, L. (1999). Havens, halos and spaghetti: untangling the evidence about foreign direct investment and the environment. Foreign direct Investment and the Environment, 13(8), 4774.https://nautilus.org/napsnet/napsnet-special-reports/havens-halos-and-spaghetti-untangling-theevidence-about-the-relationship-between-foreign-investment-and-the-environment/

- Zhang, X. P., \& Cheng, X. M. (2009). Energy consumption, carbon emissions, and economic growth in China. Ecological economics, 68(10), 2706-2712.https://doi.org/10.1016/j.ecolecon.2009.05.011

- Zhang, Y. J. (2011). The impact of financial development on carbon emissions: An empirical analysis in China. Energy policy, 39(4), 2197-2203https://doi.org/10.1016/j.enpol.2011.02.026 